\title{
MARCAS DA ORATURA EM CONTOS DE MOÇAMBIQUE
}

Camila Knebel Fenner Demétrio Alves Paz

Alfeu Sparemberger

Resumo: No presente artigo buscamos evidenciar elementos característicos do processo de oratura nas literaturas africanas de língua portuguesa, tendo como corpus de análise os dez volumes da coletânea "Contos de Moçambique", que apresentam releituras de histórias da tradição oral moçambicana. $\mathrm{Na}$ análise dos contos da coleção, consideramos a oratura como união de elementos de duas tradições - oral e escrita -, revelando características constantes dessa junção. Para evidenciá-las, nos baseamos, principalmente, nos estudos de Amadou Hampâté Bâ (2010), Vansina (2010), Moreira (2005), Portugal (1999), Fonseca (2015), Fonseca e Cury (2008), Macêdo e Chaves (2007) e Rosário (1989).

Palavras-chave: Literatura moçambicana. Oratura. Conto. Tradição oral. Escrita.

Abstract: In this essay, we seek to evidence characteristic elements of orature process in the Portuguese speaking African literatures, using as analyses corpus the ten volumes of the series "Contos de Moçambique" (Mozambique tales), which present re-writings of tales from Mozambican oral tradition. In the study of the tales of the collection, we consider orature as the union of elements of two traditions - oral and written -, revealing constant characteristics of this junction. To evidence them, we are mainly based in the studies of Amadou Hampâté Bâ (2010), Vansina (2010), Moreira (2005), Portugal (1999), Fonseca (2015), Fonseca and Cury (2008), Macêdo and Chaves (2007), and Rosário (1989).

Keywords: Mozambican Literature. Orature. Short story. Oral tradition. Writing.

Os países africanos de língua oficial portuguesa (PALOP) sofreram um enorme silenciamento sociocultural em razão da imposição de práticas da cultura europeia como forma 
de dominação. A reação pós-independência desses povos foi a de resgatar elementos culturais antes ignorados, sobrepondo-os a uma tradição determinada pelo colonizador e considerada oficial. Curtin (2010, p. 43) informa que: “Existia uma história 'colonial' oficial, que tendia a acentuar as atividades europeias e a ignorar a parte africana. [...] Mesmo no seu mais alto grau de objetividade, 'a história colonial' só outorgou aos africanos papéis secundários no palco da história". Assim, o principal desafio encontrado por essas nações, na afirmação de suas identidades, foi a dificuldade em legitimar uma herança na qual a oralidade prevalecia como principal meio para a transmissão de saberes, contrária à cultura letrada europeia. Iniciou-se, então, um movimento de apropriação da língua portuguesa como ferramenta de valorização dos costumes autóctones. Dessa maneira, os autores moçambicanos recontaram as narrativas tradicionais, atualizando-as para uma nova geração (MACÊDO; CHAVES, 2007).

Nesse processo de mescla de gêneros ocorre a representação da tradição oral por meio da escrita, percebida, em grande parte, nas obras literárias africanas de língua portuguesa. Isso é o resultado do que chamamos de oratura que, para Kandjimbo (2003, p. 15-16) vai além 
de "um acervo de textos orais que podem, presentemente, ser conservados com recurso à escrita. [...] Encerra em si as conotações de um sistema estético, um método e uma filosofia". Por meio deste método, os escritores buscam evitar que suas memórias caiam no esquecimento, resgatando, assim, histórias, conhecimentos e costumes que foram passados de uma geração a outra pela oralidade. Consequentemente, há o fortalecimento das diferentes culturas pertencentes a uma grande unidade tradicional.

Neste trabalho, buscaremos evidenciar elementos característicos do processo de oratura nas literaturas africanas de língua portuguesa, tendo como objeto de análise a coletânea completa "Contos de Moçambique", que apresenta releituras de dez contos da tradição oral moçambicana. Os títulos estudados são: $O$ Rei Mocho (2016), de Ungulani Ba Ka Khosa; As Armadilhas da Floresta (2016), de Hélder Faife; A Viagem (2016), de Tatiana Pinto; O Casamento Misterioso de Mwidja (2017), de Alexandre Dunduro; Kanova e o Segredo da Caveira (2017), de Pedro Pereira Lopes; Wazi (2017), de Rogério Manjate; Na Aldeia dos Crocodilos (2018), de Adelino Timóteo; O Caçador de Ossos (2018), de Carlos dos Santos; Leona, a filha do silêncio (2018), de Marcelo Panguana; e O Pátio das Sombras (2018), 
de Mia Couto. Para nossa análise buscamos referências nos trabalhos de Amadou Hampâté Bâ (2010), Vansina (2010), Moreira (2005), Portugal (1999), Fonseca e Cury (2008), Fonseca (2015), Macêdo e Chaves (2007) e Rosário (1989).

\section{Tradição oral e oratura}

Os PALOP possuem as raízes de sua cultura em histórias fundadoras advindas de povos existentes desde muito antes da colonização portuguesa. Boa parte das narrativas sobrevivem ainda na memória coletiva dessas nações, que, antes de uma territorialização estrangeira, eram comunidades divididas por aldeias que possuíam costumes bastante peculiares. Por esta razão, a coletânea "Contos de Moçambique", ainda que se refira às histórias tradicionais de um mesmo país, é uma grande miscelânea de contos que retrata diferentes hábitos e crenças desses povos (KHOSA, 2016; COUTO, 2018; TIMÓTEO, 2018).

Tais histórias sobreviveram ao tempo por meio da oralidade, que chamaremos de tradição oral, uma vez que, de acordo com Moreira (2005, p. 22, grifo do autor), “a palavra tradição vem do latim traditio. O verbo é tradire e significa entregar. Designa o ato de passar algo para outra pessoa, ou de passar de uma geração a outra geração". Desta forma, a tradição oral é "um testemunho transmitido oralmente de 
uma geração a outra. Suas características particulares são o verbalismo e sua maneira de transmissão, na qual difere das fontes escritas" (VANSINA, 2010, p. 140, grifo do autor). Ao confrontar-se com a cultura letrada, a tradição oral africana teve sua importância questionada, pois

tudoqueumasociedadeconsideraimportante para o perfeito funcionamento de suas instituições, para uma correta compreensão dos vários status sociais e seus respectivos papéis, para os direitos e obrigações de cada um, tudo é cuidadosamente transmitido. Numa sociedade oral isso é feito pela tradição, enquanto numa sociedade que adota a escrita, somente as memórias menos importantes são deixadas à tradição. É esse fato que levou durante muito tempo os historiadores, que vinham de sociedades letradas, a acreditar erroneamente que as tradições eram um tipo de conto de fadas, canção de ninar ou brincadeira de criança. (VANSINA, 2010, p. 146)

Todos esses fatores contribuíram para a dificuldade de valorização da tradição oral autóctone. Não cabe, neste trabalho, medir a veracidade ou não dessas histórias, contudo vale ressaltar que, para as comunidades africanas, a palavra é uma poderosa ferramenta de representatividade do próprio homem, de sua família, de sua comunidade e de seus deuses. Os contos aqui analisados são, de certa forma, parte "das memórias 
individual e coletiva e o valor atribuído à verdade em uma determinada sociedade" (HAMPÂTÉ BÂ, 2010, p. 168).

Logo, o que se dizia era tomado como verdade na tradição de cada povo pelo caráter exemplar das histórias, assim como manter a veracidade, no sentido de preservar a ocorrência dos fatos relatados originalmente ao recontar as narrativas, é vital, pois, na tradição africana, "aquele que corrompe sua palavra, corrompe a si próprio" (HAMPÂTÉ BÂ, 2010, p. 174). Além disso, não eram todos que podiam ser responsáveis por transmitir às novas gerações as narrativas tradicionais. Isso ficava por conta dos mais velhos, que eram considerados mais sábios, e dos griots, que

são trovadores que reúnem tradições em todos os níveis e representam os textos convencionados, diante de uma audiência apropriada, em certas ocasiões - casamento, morte, festa na residência de um chefe, etc. É raro não haver especialização, mesmo no nível da história da terra ou da família. (VANSINA, 2010, p. 150)

Tais testemunhos, para representar uma herança, precisam ter "uma mesma sequência de acontecimentos passados, contanto que a pessoa não tenha adquirido novas informações entre as diversas declarações. Porque, nesse último caso, a transmissão seria alterada e estaríamos diante de uma nova tradição" (VANSINA, 2010, p. 140-141). Aqui, 
o termo também possui os sentidos de informação, saber, ensinamento, porque nas sociedades africanas

a tradição oral é o veículo fundamental de todos os valores, quer educacionais, quer sociais, quer político-religiosos, quer económicos, quer culturais, apercebe-se mais facilmente que as narrativas são a mais importante engrenagem na transmissão desses valores. (ROSÁRIO, 1989, p. 40)

Por muito tempo, a oralidade foi o único meio para a conservação e a transmissão dos saberes desses povos. Ela não deve ser desqualificada, mas considerada "uma atitude diante da realidade e não a ausência de uma habilidade" (VANSINA, 2010, p. 140). A partir desta perspectiva, acreditamos ser fundamental o registro desses testemunhos por meio da escrita em uma literatura que nasceu da luta por afirmação em movimentos pré-independência e segue se reinventando contemporaneamente. Para Francisco Salinas Portugal (1999, p. 35),

a oralidade erige-se, pois, num veículo fundamental da transmissão do saber e da regulamentação dos comportamentos individuais e coletivos; neste sentido, a oralidade é uma instituição de prestígio e os "mestres da palavra" possuem um estatuto que não pode ser negligenciado.

Ao analisarmos a coleção "Contos de Moçambique" percebemos que esses escritos não são apenas a simples 
junção de dois gêneros, mas apresentam um terceiro modo de manifestação composto em meio a um movimento entre a cultura oral e a letrada. Chamaremos essa movimentação de "oratura", que, para Fonseca e Cury (2008, p. 63), é "o diálogo, nem sempre harmônico, entre formas expressivas ligadas à tradição oral e à escrita. Engloba oratura (no francês oraliture) a simultaneidade: oralidade e escrita, vazada em duplo movimento". Não há somente a transposição do oral para o escrito nesses contos, mas também uma troca entre as duas tradições - oral e escrita - compondo um sistema híbrido, com peculiaridades próprias. Pretende-se levantar aqui as especificidades recorrentes nos dez contos que justificam a hipótese de pensar a oratura enquanto um sistema estético em

uma literatura na qual os modos de dizer e de escutar afetam a textura e a ordenação do discurso retórico, os seus recursos, como um trabalho artesanal que thes empresta o estatuto de re-produção, de re-presentação da diversidade que caracteriza a cultura moçambicana. (MOREIRA, 2005, p. 20)

Nota-se que, pela oratura, há uma ordenação própria do discurso a partir do momento em que a narrativa adota elementos comuns à oralidade. Segundo Tania Macêdo e 
Rita Chaves (2007, p. 158), "a estrutura do relato remete à recuperação do universo da oratura". É o que percebemos na coletânea quando alguns elementos particulares da tradição africana aparecem nas narrativas. São eles: canções, ditos populares e adivinhas. Utilizando-se desses recursos, há a transformação dos textos em "construções literárias oralizadas que podem ser lidas, ouvidas, cantadas, teatralizadas enfim, porque, nelas, voz e gestos continuam a se exibir no corpo textual criado, inventado, urdido com letras e sons" (FONSECA, 2015, p. 126). Nessa mesma linha, Benjamim Abdala Jr. (1989, p. 23) nos esclarece que

ninguém cria do nada. Há a matéria da tradição literária que o escritor absorve e metamorfoseia nos processos endoculturativos, desde a apreensão 'mais espontânea' dos pequenos 'causos' populares, ditos populares, canções etc., da chamada oralitura ('literatura' oral) até os textos 'mais auto-reflexivos' da literatura erudita. Ocorre, nesse sentido, uma apropriação 'natural' das articulações literárias", em que se verifica a atuação do escritor como ser social e "porta-voz" de um patrimônio cultural coletivo.

Com o fortalecimento das literaturas africanas de língua portuguesa surge, como de costume na cultura letrada, a necessidade de se classificar os textos produzidos. Os contos, presentes na Coletânea analisada neste trabalho, 
foram reproduzidos e pensados na escrita do que conhecemos por literatura infantil ou infantojuvenil, pois as narrativas, em sua maioria, possuem o objetivo de proteger uma herança ancestral de caráter exemplar, baseada em uma visão de mundo totalmente distinta da europeia. Nas tradições africanas há "uma educação peculiar, ao mesmo tempo material, psicológica e espiritual, fundamentada no sentimento de unidade da vida e cujas fontes se perdem na noite dos tempos" (HAMPÂTÉ BÂ, 2010, p. 211). As histórias possuem, dessa forma, uma temporalidade mítica, comum à tradição oral, aparente também nas releituras, de tal modo que a função didática das narrativas remete à linguagem mítica, pois

- mito, representação fantástica do passado, em geral domina o pensamento dos africanos na sua concepção do desenrolar da vida dos povos. Isso a tal ponto que, às vezes, a escolha e o sentido dos acontecimentos reais deviam obedecer a um "modelo" mítico que predeterminava até os gestos mais prosaicos do soberano ou do povo. (HAMA; KIZERBO, 2010, p. 24)

Percebemos que o caráter exemplar das histórias influencia no modo como elas são narradas, denunciando o primeiro elemento específico do que entendemos por oratura nos contos da Coletânea: a narração. Além disso, 
são mantidas estruturas fixas da oralidade nas histórias: a estrutura da narrativa, os cantos, os ditos populares e as adivinhas, mantendo o movimento entre saberes coletivos que se cruzam na tradição oral. Assim, os contos mantêm "um vínculo de vaivém gerador de movimento e rito, consequentemente de vida e ação" (HAMPÂTÉ BÂ, 1993, p. 16). A seguir, esclareceremos essas impressões a partir de trechos das dez histórias da coletânea "Contos de Moçambique".

\section{Marcas da oratura em "Contos de Moçambique"}

As histórias, transmitidas oralmente nas comunidades tradicionais africanas, geralmente são agentes transformadores desses locais, pois objetivam passar alguma lição ao público ouvinte. Percebemos duas constantes nos contos: a função didática e a preservação de estruturas fixas da oralidade nas releituras. Os contos, portanto, mantêm

seu carácter exemplar. Quer isto dizer que é nas narrativas que se encontram veiculadas as regras e as interdições que determinam o bom funcionamento da comunidade e previnem as transgressões. Essas regras e interdições formam conjuntos que variam segundo as culturas, mas apresentam algumas constantes demonstrando que as narrativas na tradição oral, em geral, estão ligadas à própria vida. (ROSÁRIO, 1989, p. 40) 
A função didática é conservada nas releituras apresentadas pela Coletânea, uma vez que são passados valores sociais por meio dos contos. As "lições" aparecem de diferentes formas no decorrer dos dez volumes. Em alguns, elas manifestam-se como uma moral explícita no final do livro; em outros, baseada em ensinamentos entre família e comunidade, assim como a partir de termos e expressões próprios de cada comunidade e, por último, em mudanças no desfecho das narrativas.

A primeira obra da coletânea é O Rei Mocho, de Ungulani Ba Ka Khosa (2016), construída em forma de diálogo entre pai e filho, em uma narração que evidencia um processo natural dentro das comunidades africanas, em que são compartilhados saberes entre diferentes gerações por intermédio da oralidade. No enredo, o pai assume o papel tradicional dos griots ao contar ao menino uma história de tempos antigos, "tempos primeiros" (KHOSA, 2016, p. 9), o que concede à narrativa um efeito de sentido relacionado ao de mito, pois "o mito conta uma história sagrada; ele relata um acontecimento ocorrido no tempo primordial, o tempo fabuloso do "princípio'” (ELIADE, 2000, p. 11). Essas histórias estão dentro de um grande tempo passado, que é sagrado e deve ser respeitado. 
Assim como em outros volumes da coleção, em $O$ Rei Mocho (2016) o ser humano e os demais animais convivem em uma relação de igualdade, estabelecendo uma comunicação em que todos se entendem. Nessas histórias, "os animais, assim como os homens, revestem-se de dignidade própria e são dotados do dom da fala" (MACÊDO; CHAVES, 2007, p. 20), representam características humanas e distanciam as histórias do cotidiano. Nesse cenário, "a realidade e a imaginação cruzavam-se, casando e descasando-se. A fronteira entre imaginação e a realidade era tão frágil, que poucos conheciam a margem que as separava" (KHOSA, 2016, p. 7); o que é imaginado passa a fazer parte da realidade até que se prove que não é real, como acontece na história.

A harmonia na floresta dura até o momento em que os pássaros decidem eleger um novo guia, além da mãe natureza, para os proteger e organizar. O mocho é eleito como líder "por causa dos chifres que embelezam a sua cabeça" (KHOSA, 2016, p. 11). Ele nunca entrou em conflito com seus súditos, deixando que cada espécie se organizasse por si. O critério utilizado para sua escolha como rei, entretanto, desperta a curiosidade do homem, que $\mathrm{o}$ acusa de ter chifres falsos e, de fato, eles eram falsos. Isso desestabiliza a organização social recém-formada e 
faz com que os mochos virem inimigos dos homens. O conflito gerou desequilíbrio entre os humanos e os pássaros, gerando, no final da narrativa, uma justificativa para os pesadelos e insônias que temos até hoje: "é por causa desse ato, filho, que os pesadelos e as insônias são frequentes nos homens, quando os mochos, querendo a expiação humana, se abeiram das casas e começam a piar pela noite adentro" (KHOSA, 2016, p. 18). Justificativas desse tipo são características dessas histórias. Elas surgem na intenção de explicar algo que não é compreendido pelas comunidades, pois

em outros termos, o mito narra como, graças às façanhas dos Entes Sobrenaturais, uma realidade passou a existir, seja uma realidade total, o Cosmo, ou apenas um fragmento: uma ilha, uma espécie vegetal, um comportamento humano, uma instituição. É sempre, portanto, a narrativa de uma "criação": ele relata de que modo algo foi produzido e começou a ser. (ELIADE, 2000, p. 11)

No fim da narrativa aparece, em destaque, depois do diálogo entre as personagens, o dito popular "quem deita mau olhado sobre si o deita" (KHOSA, 2016, p. 18), como se fosse uma conclusão para a história, como se ela tivesse um fim, um objetivo, uma razão de ser. Outra narrativa que apresenta uma espécie de moral é As Armadilhas da Floresta, 
de Hélder Faife (2016). Há vários ensinamentos no decorrer do livro com o intuito de fazer com que o leitor/ouvinte reflita, como em: "o homem aprendeu a lição, percebeu que a natureza é muito delicada e passou a respeitá-la" (FAIFE, 2016, p. 21).

Em O Pátio das Sombras, de Mia Couto (2018), há um ensinamento tal como nas duas histórias analisadas anteriormente. A avó explica ao neto um modo diferente de lidar com a morte:

A velha sentou-se no parapeito do poço e disse ao neto que lhe ia contar um segredo. Então, ela confessou que os filhos mortos moravam vivos dentro da sua cabeça. À medida que os filhos iam morrendo a cabeça começava a tornar-se muito grande. E começou-lhe a pesar muito. Foi a partir daquele momento que deixou de poder sair de casa. Quando ela ficava só, os habitantes da sua cabeça eclodiam: raparigas, mulheres com filhos, homens, rapazes. E festejavam a vida no pátio da casa. A bem dizer, o mundo inteiro se transformava no terreiro da sua casa. (COUTO, 2018, p. 14)

Percebemos claramente, aqui, o diálogo entre o saber mítico ancestral e um tempo diferente, o do neto, que, ao final do conto, expõe o seu entendimento sobre o que a avó Ihe contou: "O menino então entendeu: o sonho era como os falecidos visitavam os vivos e festejavam a Vida. E desde 
esse dia, sempre que ele queria, dançava e cantava com o seu pai nesse infinito a que chamam 'sonho'" (COUTO, 2018, p. 19). A conclusão do menino faz com que entendamos a história fabulosa da avó como uma metáfora para passar uma mensagem de alento a ele, que perdeu o pai ainda muito novo. O menino relaciona essa mensagem com a ideia de sonho, o que parece ser mais plausível na sua visão.

Quando se trata da morte, muitas vezes essas histórias surgem com o objetivo de confortar alguém, trazendo uma explicação fantástica para o fato ocorrido, mascarando, dessa forma, fatos cruéis da realidade. Também percebemos isso no conto $A$ viagem, de Tatiana Pinto (2016), no qual os dois irmãos tentam matar a irmã deles, Inaya, mas surge um peixe mágico para salvá-la. Acreditamos que essas histórias tenham uma função de iniciação dos sujeitos, tarefa parecida com a da literatura infantojuvenil, que tem como um de seus objetivos, para além de formar novos leitores, trazer formas de lidar com situações do mundo.

A relação entre avô/avó e neto está presente em três volumes da coleção. Além do conto de Mia Couto (2018), ela aparece em Wazi, de Rogério Manjate (2017) e no livro Na Aldeia dos Crocodilos, de Adelino Timóteo (2018), representando a sabedoria dos mais velhos, que é muito 
valorizada nessas comunidades. O neto aprende a arte da caça com seu avô em Wazi (2017), mas acaba não seguindo um de seus últimos ensinamentos, que era o de, na volta da caça, não comer as frutas do lado direito do caminho. Ao ser questionado do porquê pelo menino, o velho simplesmente respondeu: "Não deves e pronto! Foi sempre assim, com todos os outros caçadores da família" (MANJATE, 2017, p. 8), o que reforça a ideia de seguir um saber ancestral inquestionável. Depois da morte do avô, Wazi seguiu o ofício de caçador, e, um dia, aquelas frutas do lado direito estavam tão saborosas que não resistiu; subiu numa árvore e começou a comê-las. O rapaz deu-se por conta que a noite havia chegado e já estava na hora de ir para casa, contudo uma força estranha o prendia na árvore; ele não conseguia se desvencilhar de seus ramos. Ali, então, entendeu o porquê do conselho de seu avô. Nos contos da coleção é comum as personagens acabarem, por bem ou por mal, confirmando os saberes ancestrais, proporcionando uma noção de causa e efeito. Vansina (2010, p. 155) afirma que

a noção de causa está implícita em toda tradição oral. Geralmente, é apresentada na forma de causa imediata e separada para cada fenômeno. Cada coisa tem uma origem, que se situa diretamente no início dos tempos. Pode-se compreender melhor o que é a causalidade examinando-se as causas 
atribuídas ao mal. Muito frequentemente elas têm relação direta com a feitiçaria, os ancestrais, etc., e a relação é imediata. Resulta desse tipo de causalidade que a mudança é percebida sobretudo em alguns campos claramente definidos, como a guerra, sucessão real, etc.

No livro Na Aldeia dos Crocodilos (2018) toda a comunidade segue as tradições. Neste conto, o avô Boaventura relatava ao neto histórias de seu povo. O mais novo, chamado Mandonguinhas, era "o menos crente daqueles relatos dos mais velhos sobre homens crocodilos ou crocodilos homens. Ainda assim, seguia o avô por fidelidade e pelo respeito que sentia pelo seu 'mais-velho'" (TIMÓTEO, 2018, p. 7). Nas comunidades africanas os mais velhos são considerados os mais sábios por sua experiência e por conhecerem as tradições:

Nessas sociedades, o homem é sempre significado pelo que aprendeu com os mais velhos, e esse aprendizado é naturalmente passado aos que vêm depois dele, como forma de garantir a coesão do grupo. Do mesmo modo, o culto à palavra dos antepassados encarna-se no culto ao mais velho, que é respeitado em virtude do saber que detém. (FONSECA; CURY, 2008, p. 79)

Boaventura contava ao neto sobre os espíritos e os homens crocodilos que povoavam o rio perto da aldeia 
onde viviam. Sempre que alguém desaparecia, os mais velhos sabiam que era por conta dos homens crocodilos que aprisionavam pessoas no fundo do rio. Ninguém jamais conseguiu impedir os raptos, até que o avô do menino sumiu e Mandonguinhas, ao investigar o sumiço, descobriu que tudo aquilo era verdade, reafirmando a legitimidade do saber ancestral, assim como acontece em Wazi (2017). Mandonguinhas, então, entrou em guerra contra seres visíveis e invisíveis para resgatar seu avô, que, ao final do conto, conseguiu voltar à aldeia.

Em A viagem (2016), a autora Tatiana Pinto apresenta a história de uma família de pescadores composta pelo casal, Masud e Wimbo, por dois filhos homens, Agot e Mbuio, e por uma filha mulher, Inaya. A família faz parte de uma aldeia bastante conservadora, cuja organização social apresenta lugares distintos a serem ocupados por homens e mulheres. Mesmo dentro desse contexto, a mãe de Inaya sempre fez questão de dar a mesma educação e incentivo para os três filhos, mesmo o pai não concordando muito com a postura de sua esposa. A mãe segue, ao longo do texto, motivando a filha: "lembra-te de que aconteça o que acontecer, és nossa filha, és a minha filha. Sei que és capaz e que nada te aterroriza! És forte e vais continuar a ser forte!" (PINTO, 2016, 
p. 12). Durante toda a história Inaya vence os tabus impostos pela sociedade com a qual tem contato, enfatizando um desejo de igualdade entre os gêneros. Dessa forma, também percebemos que as releituras servem para criticar certos aspectos tradicionais, atualizando a cultura ancestral com o intuito de evitar a repetição de costumes que não são mais aceitos na sociedade.

Em O Casamento Misterioso de Mwidja, de Alexandre Dunduro (2017), a personagem principal, Mwidja, também nasce em uma família humilde e conservadora. Ela e seu irmão Zwiriro davam-se muito bem, pois "os pais, desde cedo, ensinaram os filhos a respeitar as tradições e a importância de se manterem unidos" (DUNDURO, 2017, p. 6). Apesar da tradição, a educação dos dois jovens, como em A Viagem (2016), sempre foi de forma igual, sem restrições de gênero,

mas os vizinhos, que nunca tinham visto uma mulher fazer tarefas que tradicionalmente cabiam aos homens, e os homens a fazer trabalhos que normalmente eram realizados pelas mulheres, riam-se dizendo que Mwidja nunca se casaria e que Zwiriro era fraco e nunca seria um grande caçador. (DUNDURO, 2017, p. 7)

Positivamente, no conto, as personagens não se deixam influenciar pelo conservadorismo. O casamento, entretanto, ainda é considerado "dever social" da mulher e muito 
se fala sobre com quem ou como Mwidja vai se casar, tal como ocorre no conto Leona, A Filha do Silêncio, de Marcelo Panguana (2018), nono volume da coleção.

Nesse volume da coleção, contudo, percebemos o rompimento dessa tradição pela interferência que o autor faz no conto original. Na releitura, temos a história de Leona, uma jovem leoa silenciosa que não proferia palavra alguma desde que se apaixonou por um humano, o Pastorinho. Ele procurava por um bode de ouro, animal sagrado na crença de seu povo, por isso não ficou junto de Leona para se casarem. A aldeia de Leona preocupava-se com a sua desolação e aquele silêncio todo, pois daquele jeito ela não conseguiria se casar. Em uma medida desesperada, os pais de Leona resolveram entregar a mão da filha àquele que conseguisse fazê-la falar. Na releitura, ninguém consegue fazer isso. Um dia Leona foi a uma gruta e lá estava o bode com chifres de ouro. $O$ bode lhe ofereceu um pedido e, sem pensar duas vezes, Leona pediu para ver Pastorinho e seus olhos azuis novamente. $\mathrm{O}$ homem apareceu imediatamente, e ela ficou tão feliz que sua voz voltou em um grito que toda aldeia escutou. Os dois casaram-se, após a cerimônia, montaram no bode com chifres de ouro e "desapareceram pelos céus da Floresta!" (PANGUANA, 2018, p. 17). 
Já no conto original, a história segue um outro rumo a partir do momento em que os pais de Leona oferecem a mão da filha àquele que conseguisse fazê-la falar. O coelho, animal que aparece sempre como astuto na maioria dos contos africanos e fábulas, usa de um truque para fazer Leona falar e acaba ganhando a mão da jovem leoa, casando-se com ela à força. A partir da releitura, o autor rompe com o costume de o pai entregar a mão da filha a alguém, ela gostando ou não do pretendente, levando adiante a crítica à tradição. $\mathrm{Na}$ releitura a narrativa adapta-se a um novo contexto social, fazendo um movimento que é comum em meio à tradição oral que, muitas vezes, reorganiza suas histórias de acordo com o interlocutor, ouvinte ou objetivo. A oratura, presente nas releituras, mantém esse movimento, havendo uma

$$
\begin{aligned}
& \text { adequação de cada narrativa a novas } \\
& \text { condições sociais, onde deve poder } \\
& \text { continuar a cumprir o seu papel de educar, } \\
& \text { entreter, conservar e veicular os valores da } \\
& \text { colectividade... No fundo, é este fenómeno } \\
& \text { de constante actualização que demonstra a } \\
& \text { natureza viva que as narrativas possuem na } \\
& \text { oralidade. (ROSÁRIO, 1989, p. 11) }
\end{aligned}
$$

A maneira de se contar as histórias na Coletânea segue uma estrutura hegemônica na tradição oral que, por meio da oratura, é mantida nos contos. As narrativas seguem a ordem cronológica clássica dos acontecimentos, em que aparecem, 
respectivamente, início, meio e fim. Alguns dos contos ainda começam com "Era uma vez", adotando a forma clássica de iniciar narrativas na tradição escrita. Seguindo essa estrutura, temos, em primeiro lugar, uma ambientação da história, a exposição das características do locus por meio da descrição de elementos da natureza ou da comunidade em que se passa a história, para, em seguida, fazer a descrição das personagens e a definição de suas personalidades mediante suas ações ao longo do enredo.

O oitavo volume da coleção, O Caçador de Ossos, de Carlos dos Santos (2018), começa seguindo exatamente a estrutura descrita anteriormente: "Era uma vez... Uma aldeia distante, entalhada na encosta verdejante duma montanha majestosa, no lado oposto àquele de onde o Sol nascia" (SANTOS, 2018, p. 5). Sinaportar, personagem principal do conto, vivia nessa aldeia e era um jovem caçador muito famoso por conta da sua sorte nas caças. Todo o povo acreditava que ele era abençoado pelos deuses, mas, na verdade, quem caçava eram seus cães. Ele ficava com toda glória e toda carne, dando aos animais apenas ossos e farinha, até o dia em que eles se revoltaram e pararam de caçar em protesto ao tratamento que recebiam de seu dono. O rapaz achou que tinha sido amaldiçoado, por 
isso foi visitar o curandeiro da aldeia que the revelou o verdadeiro problema e fez com que o rapaz mudasse suas atitudes: "Aqueles que trabalham, que enfrentam os riscos e fazem sacrifícios não podem ser esquecidos quando chega à altura de usufruir dos benefícios" (SANTOS, 2018, p. 20), disse o curandeiro.

Geralmente, nos contos tradicionais, existem personagens estereotipados que carregam a palavra da sabedoria ou possuem vozes de comando que influenciam as ações da personagem principal por meio de seus ensinamentos, como é o caso do curandeiro neste conto. Graças a ele, Sinaportar mudou sua postura: "com essa mudança ele perdeu a antiga fama de caçador inigualável. Mas conquistou o estatuto de homem de grande valor, porque, a cada dia que passava, o Sinaportar se tornava melhor do ele próprio fora no dia anterior" (SANTOS, 2018, p. 21). Outros contos que também apresentam estereótipos são: os chefes de aldeia, em A Aldeia dos Crocodilos (2018), o leão, em Armadilhas da Floresta (2016), a velha feiticeira, em A Viagem (2016), a caveira falante, representação de um saber ancestral, em Kanova e o Segredo da Caveira (2017), a figura do mais velho, como o avô, de Wazi (2017), e a avó do menino, em O Pátio das Sombras (2018). 
Observamos que, em todos os volumes da Coleção, alguns termos e expressões próprias do dialeto de algumas comunidades são mantidos, como no seguinte trecho de $\mathrm{Na}$ Aldeia dos Crocodilos (2018): "as mulheres se dedicavam à machamba e os homens à pesca" (TIMÓTEO, 2018, p. 11, grifo do autor), em que machamba significa "horta, pequena plantação" (TIMÓTEO, 2018, p. 23). Os significados desses termos específicos são colocados no final de cada livro, com exceção do volume 10, em que são postos como nota de rodapé. Segundo Moreira (2005, p. 123), “dicionarizado, o discurso didático da tradição empresta aos textos uma função de registro". Por mais que esses autores se apropriem da língua portuguesa para representar histórias da tradição oral, não deixam de incorporar alguns aspectos identitários da língua de cada comunidade, defendendo, assim, a origem das histórias e transparecendo um desejo de reconhecimento dessas culturas.

As estruturas fixas da oralidade, como cantos, ditos populares e adivinhas, também estão presentes nos contos. Tais estruturas aparecem nas releituras porque atravessam as narrativas na tradição oral e fazem parte de um saber popular que, na oralidade, não se dissocia dos contos. Por meio da oratura, percebemos que essas manifestações 
concedem à narrativa um aspecto vivo. Dessa forma, "[...] a fala se torna escrita. E a escrita, a fala ritualizada no papel" (MACÊDO; CHAVES, 2007, p. 26). A movimentação de diferentes elementos da oralidade, para além do registro, apresenta a ideia de rito, evidenciando o poder da palavra dentro das tradições africanas, pois

a fala pode criar a paz, assim como pode destrui-la. É como fogo. Uma única palavra imprudente pode desencadear uma guerra, do mesmo modo que um graveto em chamas pode provocar um grande incêndio. [...] A fala, por excelência, é o grande agente ativo da magia africana. (HAMPÂTÉ BÂ, 2010, p. 173)

Em O Rei Mocho (2016) temos canções direcionadas especificamente à natureza, posto que nas tradições africanas há uma forte relação espiritual com o meio ambiente. Ele é considerado fonte de equilíbrio entre os seres, uma força superior que deve ser respeitada e protegida. Nessa cultura, os ritos e as canções fazem parte de uma tentativa de manter a harmonia entre a natureza, o homem e os demais seres visíveis ou invisíveis, de acordo com a crença de cada povo,

uma vez que se considera a natureza como viva e animada pelas forças, todo ato que a perturba deve ser acompanhado de um "comportamento ritual" destinado a preservar e salvaguardar o equilíbrio 
sagrado, pois tudo se liga, tudo repercute em tudo, toda ação faz vibrar as forças da vida e desperta uma cadeia de consequências cujos efeitos são sentidos pelo homem. (HAMPÂTÉ BÂ, 2010, p. 188)

Na reescrita de Ungulani Ba Ka Khosa, as canções aparecem no diálogo entre pai e filho. O mais velho canta, pedindo licença para começar a contar uma história ao filho, ritualizando, assim, essa prática e a transformando em um ato cultural, como vemos no seguinte diálogo entre pai e filho:

- Conta-me.

- Vamos cantar primeiro à mãe árvore. A protetora dos espíritos.

J Zu, zuum, zuum, zuum

Abre-me a porta, mãe árvore! Abre, abreme a porta!

Quem és tu?

Zu, zuum, zuum, zuum

Sou eu teu filho, homem, mãe árvore.

Sou eu, teu filho homem!

Que queres, pés compridos?

$\mathrm{Zu}$, zuum, zuum, zuum

A proteção dos espíritos, mãe árvore.

Do olhar do mocho!

Zu, zuum, zuum, zuum

Abre-me a porta, mãe árvore.

A porta está aberta.

Que a paz esteja contigo, mãe árvore.

Zu, zuum, zuum, zuum JJ

(KHOSA, 2016, p. 7) 
Trechos da canção seguem sendo repetidos no decorrer da narrativa, em um ritual praticamente religioso.

Em O Casamento Misterioso de Mwidja (2017) também aparecem canções direcionadas à natureza, só que agora especificamente ao Flamingo, amigo de Zwiriro, irmão de Mwidja. É uma canção que cumpre a função de chamado, pois o Flamingo ensina a música a Zwiriro para que o menino o chamasse quando estivesse em perigo. Na letra há, também, o resgate de dialetos das comunidades tradicionais, assim como o autor traz na composição original e sua tradução:

\footnotetext{
J Tchekwe chamwari tchangu iwe, mburuka hako.

Tchekwe chamwari tchangu iwe, mburuka hako, isai condiponessa.

Voa, meu amigo flamingo.

Voa, meu amigo flamingo, vem me salvar. J $\delta$ (DUNDURO, 2017, p. 12)
}

Mwidja resolveu casar-se com alguém de fora da aldeia e levou o irmão junto. Os dois jovens foram muito bem recebidos ao chegarem na aldeia do noivo, porém ficaram espantados com a quantidade de ossos espalhados pelo local. O noivo mentiu que existiam muitos caçadores por lá, mas Zwiriro descobriu a verdade durante a madrugada: ele viu todos os homens da aldeia em um ritual no qual cantavam um "cântico da transformação. À medida que 
cantavam, iam-se transformando, um a um, em hienas" (DUNDURO, 2017, p. 14). O canto sempre fez parte da cultura das comunidades africanas que "conservam hábitos característicos do uso da palavra com uma função mágica" (FONSECA; CURY 2008, p. 76). Após o menino mostrar à irmã a verdade, Mwidja começa a gritar. Os homens-hienas, então, se aborrecem e decidem atacar os dois irmãos, que são salvos pelo Flamingo graças à canção que ele ensinou a Zwiriro. O menino continua comunicando-se com o Flamingo por meio de músicas e, assim, percebemos que os cânticos acabam assumindo várias funções na narrativa:

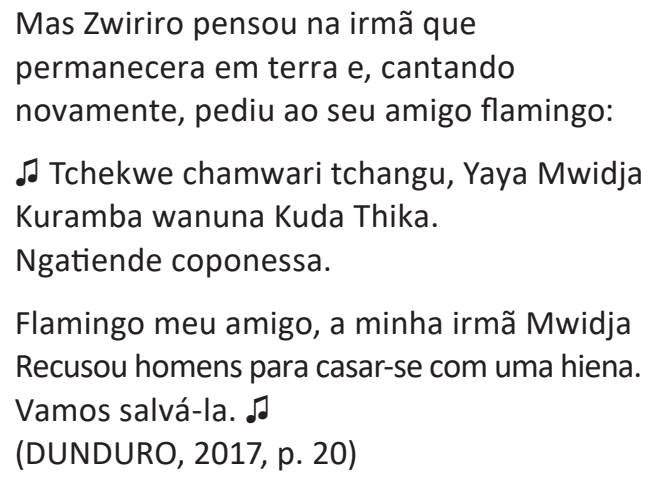

Em $O$ pátio das Sombras não temos uma canção específica mencionada durante a história, mas a avó canta ao neto para fazê-lo adormecer e sonhar, mostrando ser uma prática comum na tradição oral e assumindo, aqui, mais uma função diferente: "a velha convidou o neto para 
que se sentasse a seu lado, de mãos dadas, e se deixasse sonhar. Ela Ihe foi cantando uma canção de embalar" (COUTO, 2018, p. 15). A música serve para embalar, para ritualizar as próprias histórias, para reforçar a crença em entes superiores e dar uma função mágica à palavra.

Em Wazi (2017) há a utilização de ditos populares que também são uma manifestação comum da oralidade: "como diz o povo, quem sai aos seus não degenera" (MANJATE, 2017, p. 7). Tais ditos representam uma memória coletiva que permeia as narrativas e estão ali por uma razão - "o manuseio de provérbios e ditos populares revela o teor persuasivo de seu discurso, expresso através do emprego constante de mecanismos retóricos calcados em argumentos extraídos do saber da tradição ancestral" (MOREIRA, 2005, p. 103). Relacionando-os com fatos ocorridos na narrativa, se "reitera o valor atribuído à sabedoria dos antigos" (FONSECA; CURY, 2008, p. 64).

No conto Kanova e o Segredo da Caveira (2017) o saber popular é representado por adivinhas. O texto é sobre um rei que quer uma coroa nova, diferente de qualquer uma já vista. Para realizar seu desejo, precisariam de materiais de fora do reino, porém não havia homens, além da sua guarda pessoal, para buscá-los, uma vez que todos tinham partido 
em campanhas militares. Não conformado, o rei decretou que os rapazes com mais de dez anos fossem procurar materiais para criação de sua nova coroa.

O menino Kanova, então, despede-se da mãe e começa sua jornada. No caminho encontra uma caveira falante que Ihe aconselha e Ihe ajuda durante o trajeto. Tudo corria bem até os dois encontrarem um grupo de leopardos famintos. Para não ser devorado Kanova tenta comunicar-se com os animais, que decidem propor um acordo ao menino: para se salvar ele deveria responder corretamente uma adivinha. A pergunta foi a seguinte: "é mais forte do que o braço do elefante; o seu rugido é mais forte do que o do leão; as árvores ajoelham-se perante ele e é mais rápido do que qualquer leopardo?" (LOPES, 2017, p. 10). O menino responde:

- Já sei! É O VENTO! Só o vento pode ser mais forte do que o elefante e mais potente do que o rugido do leão. Quando sopra, com a sua força, as árvores curvam-se tanto até parecerem ajoelhar-se. E quem mais rápido do que qualquer um de vós, se não o vento? (LOPES, 2017, p. 12)

O menino acertou a resposta da adivinha e ainda levou uma pele de leopardo para fazer a coroa. No caminho encontrou pavões que o presentearam com suas penas, porque ficaram com dó dele pelo fato de o menino estar tanto tempo longe da mãe. No reino onde Kanova morava "as mães choravam 
tanto pelos filhos que não regressavam, que as lágrimas se juntaram e formaram um rio de onde partiam torrentes de saudades em todas as direções" (LOPES, 2017, p. 14). Ao regressar, Kanova contou toda a história ao rei e às pessoas que estavam no palácio, inclusive a parte da caveira falante. O rei duvidou e pediu para que o rapaz lhe mostrasse a caveira, apostando o seu trono que era mentira do garoto. A caveira acabou falando e provou que o que Kanova dizia era verdade; todos espantaram-se; “aquilo era lição de outro mundo, de onde moravam os antepassados - uma benção" (LOPES, 2017, p. 18). Kanova acabou tornando-se o novo mambo (rei) de Mopeia, reino onde vivia.

\section{Considerações finais}

Os textos literários analisados neste artigo são escritos por autores moçambicanos, isto é, aqueles que produzem a série literária nacional, que firma e afirma a literatura do país. Desse modo, eles se apropriam de outras séries, culturais e literárias, em sua produção e, assim, inscrevem a sociedade e a cultura no texto. Os textos não são produções dos griots, dos contadores, mas textos literários escritos a partir dessa tradição oral e filtrados por uma tradição escrita.

Percebemos que a oratura, sistematizada neste trabalho, é muito mais que a junção de dois gêneros: oral e escrito. Faz 
parte de um ato cultural que está em constante movimento, mesmo que materializado pela escrita, pois sua narrativa faz sentir e ter-se contato com diferentes manifestações literárias. As considerações aqui são feitas com base na análise da Coletânea "Contos de Moçambique"; logo, não podemos generalizar as características e estipular um conceito fixo e dado como pronto para oratura. Acreditamos, contudo, que a análise caminha para o levantamento de especificidades que podem ser relacionadas a ela.

O contato com as literaturas africanas de língua portuguesa abre a visão para culturas humanizadoras que aproximam o leitor de um significado mágico para a vida, de tal forma que:

Existe, pois, um pacto entre o autor e o leitor de textos africanos, segundo o qual o texto escrito prolonga o texto oral, numa espécie de "miragem" oral de fortes conotações ideológicas, de clara instrumentalização da leitura (facilitando a recepção do texto desde um contexto que lhe é natural e conhecido ao leitor) e um evidente repositório de recursos literários que acabam por ser marcas de originalidade africana. (PORTUGAL, 1999, p. 38-39)

A análise levou a reflexões sobre a importância da literatura para jovens e o seu papel na sociedade. Na maioria dos textos há a representação da vida em comunidade, de 
modo que "contribui para enriquecer, ao mesmo tempo, o conhecimento geral da língua, da literatura, do pensamento coletivo e das estruturas sociais da civilização estudada" (VANSINA, 2010, p. 164). Tendo em vista que sempre há novas considerações a serem feitas, porque "o espaço da literatura é, assim, o espaço de trânsito, migrações e traduções" (FONSECA; CURY, 2008, p. 82), pretendemos continuar os estudos nesta área com o objetivo de descobrir novos desdobramentos da oratura dentro de textos das literaturas africanas de língua portuguesa.

\section{Referências}

ADBALA JR., Benjamin. Literatura, História e Política. São Paulo: Ática, 1989. COUTO, Mia. O pátio das sombras. Contos de Moçambique, v. 10. São Paulo: Editora Kapulana, 2018.

CURTIN, Philip D. Tendências recentes das pesquisas históricas africanas e contribuição à história em geral. In: KI-ZERBO, Joseph (Ed.). História geral da África I: metodologia e pré-história da África. 2. ed. Brasília: Unesco, 2010. DUNDURO, Alexandre. O casamento misterioso de Mwidja. Contos de Moçambique, v. 4. São Paulo: Editora Kapulana, 2017.

ELIADE, Mircea. Mito e realidade. São Paulo: Perspectiva, 2000.

FAIFE, Hélder. As armadilhas da floresta. Contos de Moçambique, Vol. 2. São Paulo: Editora Kapulana, 2016.

FONSECA, Maria Nazareth Soares; CURY, Maria Zilda Ferreira. Mia Couto: espaços ficcionais. Belo Horizonte: Autêntica Editora, 2008.

FONSECA, Maria Nazareth Soares. Literaturas africanas de Língua Portuguesa: mobilidades e trânsitos diaspóricos. Belo Horizonte: Nandyla, 2015. 
HAMA, Boubou; KIZERBO, Joseph. Lugar da história na sociedade africana. In: KI-ZERBO, Joseph (Ed.). História geral da África I: metodologia e pré-história da África. 2. ed. Brasília: Unesco, 2010. HAMPÂTÉ BÂ, Amadou. Palavra africana. O correio da Unesco, Paris; Rio de Janeiro, ano 21, n. 11, novembro de 1993.

HAMPÂTÉ BÂ, Amadou. A tradição viva. In: KI-ZERBO, Joseph (Ed.). História geral da África I: metodologia e pré-história da África. 2. ed. Brasília: Unesco, 2010. KANDJIMBO, Luis. Provérbios angolanos na literatura oral. Revista Austral, Luanda: TAAG, n. 45, julho/agosto/setembro de 2003. KHOSA, Ungulani Ba Ka. O rei mocho. Contos de Moçambique, v. 1. São Paulo: Editora Kapulana, 2016.

LOPES, Pedro Pereira. Kanova e o segredo da caveira. Contos de Moçambique, v. 5. São Paulo: Editora Kapulana, 2017.

MACÊDO, Tania; CHAVES, Rita. Literaturas de língua portuguesa: marcos e marcas - Angola. São Paulo: Arte \& Ciência, 2007.

MANJATE, Rogério. Wazi. Contos de Moçambique, v. 6. São Paulo: Editora Kapulana, 2017.

MOREIRA, Terezinha Taborda. O vão da voz: a metamorfose do narrador na fiç̧ão moçambicana. Belo Horizonte: Ed. PUC Minas, 2005.

PANGUANA, Marcelo. Leona, a filha do silêncio. Contos de Moçambique, v. 9. São Paulo: Editora Kapulana, 2018.

PINTO, Tatiana. A viagem. Contos de Moçambique, v. 3. São Paulo:

Editora Kapulana, 2016

PORTUGAL, Francisco Salinas. Entre Próspero e Caliban: literaturas africanas de língua portuguesa. Santiago de Compostela: Laiovento, 1999. ROSÁRIO, Lourenço Joaquim da Costa. A narrativa africana de expressão oral: transcrita em português. Lisboa: Icalp, 1989.

SANTOS, Carlos dos. O caçador de ossos. Contos de Moçambique, v. 8. São Paulo: Editora Kapulana, 2018.

TIMÓTEO, Adelino. Na aldeia dos crocodilos. Contos de Moçambique, v. 7. São Paulo: Editora Kapulana, 2018. 
VANSINA, Joseph. A tradição oral e sua metodologia. In: KI-ZERBO, Joseph (Ed.). História geral da África I: metodologia e pré-história da África. 2. ed. Brasília: Unesco, 2010.

\section{Camila Knebel Fenner}

Mestranda em Letras no Programa de Pós-graduação em Letras da Universidade Federal de Pelotas.

Lattes: http://lattes.cnpq.br/7785423886043689

ORCID iD: https://orcid.org/0000-0002-3757-8733

\section{Demétrio Alves Paz}

Doutor em Letras (PUCRS).

Professor Associado de Teoria Literária e Literaturas de Língua Portuguesa na Universidade Federal da Fronteira Sul (UFFS) - Cerro Largo - RS, coordenador de projetos de pesquisa na área das literaturas africanas de língua portuguesa e da literatura afro-brasileira.

Possui artigos publicados nas revistas Abril, Via Atlântica, Nau Literária, Terra Roxa e outras terras, Boitatá, entre outras, versando principalmente sobre literaturas africanas e ensino de literatura.

Lattes: http://lattes.cnpq.br/2272620373111968

ORCID iD: http://orcid.org/0000-0002-5305-290X

\section{Alfeu Sparemberger}

Doutor em Letras (USP).

Professor do Centro de Letras e Comunicação da Universidade Federal de Pelotas (UFPEL) e Professor do Programa de Pós-Graduação em Letras da UFPEL, coordenador de projetos de pesquisa na área das literaturas de língua portuguesa.

Possui artigos publicados nas revistas Antares, Anuário de Literatura, Navegações, Signótica, entre outras, versando principalmente sobre literaturas de língua portuguesa.

Lattes: http://lattes.cnpq.br/9671613350365467

ORCID iD: https://orcid.org/0000-0001-6003-6353 